Supporting Information

\title{
Polar Recognition Group Study of Keap1-Nrf2 Protein-Protein Interaction Inhibitors
}

Meng-Chen Lu, ${ }^{\mathrm{a}}$ Shi-Jie Tan, ${ }^{\mathrm{a}}$ Jian-Ai Ji, ${ }^{\mathrm{a}}$ Zhi-Yun Chen, ${ }^{\mathrm{a}}$ Zhen-Wei Yuan, ${ }^{\mathrm{a}}$ Qi-Dong You, ${ }^{\mathrm{a}, \mathrm{b}}$ * and Zheng-Yu Jiang ${ }^{\mathrm{a}, \mathrm{b}}$ *

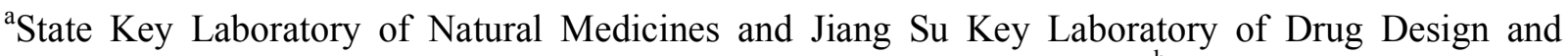
Optimization, China Pharmaceutical University, Nanjing 210009, China; ${ }^{\mathrm{b}}$ Department of Medicinal Chemistry, School of Pharmacy, China Pharmaceutical University, Nanjing 210009, China

Table of Contents:

S1. Materials and methods

S2. Densitometric analysis of the relative ratios of each proteins in western blot assay.

References 


\section{S1. Materials and methods}

\section{Chemistry}

Reactions were monitored by thin-layer chromatography (TLC) on $0.25 \mathrm{~mm}$ silica gel plates with fluorescent indicator $\left(\mathrm{GF}_{254}\right)$ and visualized under UV light. Melting points were determined with a Melt-Temp II apparatus. The ${ }^{1} \mathrm{H}$ NMR and ${ }^{13} \mathrm{C}$ NMR spectra were measured on a Bruker AV-300 instrument using deuterated solvents with tetramethylsilane (TMS) as an internal standard. ESI-mass and high resolution mass spectra (HRMS) were recorded on a Water Q-Tof micro mass spectrometer. Purity ( $\geq 95 \%$ ) of target compounds was determined by the HPLC study performed on Agilent C18 $(4.6 \mathrm{~mm} \times 150 \mathrm{~mm}, 3.5 \mu \mathrm{m})$ column using a mixture of solvent methanol/water 70:30 methanol:water with 1\% TFA) at the flow rate of $0.5 \mathrm{~mL} / \mathrm{min}$ and peak detection at $254 \mathrm{~nm}$ under UV. The ${ }^{1} \mathrm{H}$ NMR spectrums of all the titled compounds exhibited a doubling of signals, which was also reported previously by Jain et al.'s ${ }^{1}$ and our group ${ }^{2}$. Considering the elements of symmetry suggested by the planar structure, this phenomenon was quite surprising and interesting. Jain et al. has specifically demonstrated this phenomenon and gave suficient explanation on it. ${ }^{1}$

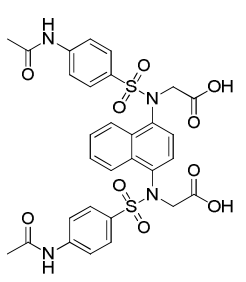

\section{2,2'-(naphthalene-1,4-diylbis(((4-acetamidophenyl)sulfonyl)azanediyl))diacetic} acid (2): To a solution of compound $6(696 \mathrm{mg}, 1 \mathrm{mmol})$ in $\mathrm{MeOH} / \mathrm{H}_{2} \mathrm{O}(8 \mathrm{~mL} / 4$ $\mathrm{mL})$ was added $\mathrm{LiOH}(1.5 \mathrm{~g})$. After $6 \mathrm{~h}$ stirring at room temperature, the reaction mixture was then diluted in $30 \mathrm{~mL}$ water and quenched with $2 \mathrm{M}$ hydrochloric acid to $\mathrm{pH}$ 5. The crude product was obtained through filtration. Recrystallization from ethyl acetate/n-hexane give the compound 11 as a light pink soild, yield $68 \%$; m.p.: $288-290^{\circ} \mathrm{C}$; ${ }^{1} \mathrm{H}-\mathrm{NMR}(300 \mathrm{MHz}, \mathrm{DMSO}, \delta) 10.74$ (s, 1H), 10.47 (s, 1H), 8.35 (dd, 1H, $J=6.23,3.08 \mathrm{~Hz}$ ), 8.18 (dd, 1H, $J=6.36,3.06 \mathrm{~Hz}), 7.90(\mathrm{~d}, 2 \mathrm{H}, J=8.61 \mathrm{~Hz}), 7.74(\mathrm{~d}, 2 \mathrm{H}, J=8.73 \mathrm{~Hz}), 7.58-7.55(\mathrm{~m}, 6 \mathrm{H})$, $7.11(\mathrm{~s}, 1 \mathrm{H}), 6.82(\mathrm{~s}, 1 \mathrm{H}), 4.48-4.28(\mathrm{~m}, 4 \mathrm{H}), 2.17(\mathrm{~s}, 3 \mathrm{H}), 2.09(\mathrm{~s}, 3 \mathrm{H}) ;{ }^{13} \mathrm{C} \mathrm{NMR}(75 \mathrm{MHz}$, DMSO-d $\left.{ }_{6}\right) \delta 170.37,169.40,169.17,143.52,143.35,137.02,133.20,132.85,131.96,130.86$, $128.95,128.71,128.58,126.74,126.26,125.99$, 125.61, 124.99, 124.64, 118.94, 118.30, 118.18, 54.34, 54.07, 43.81, 24.09; HRMS (ESI): found $686.1614\left(\mathrm{C}_{30} \mathrm{H}_{32} \mathrm{~N}_{5} \mathrm{O}_{10} \mathrm{~S}_{2} \text {, [M+NH}\right]^{+}$, requires 686.1585); HPLC (70 : 30 methanol : water with $1 \%$ TFA ): $t_{R}=3.3 \mathrm{~min}, 98.5 \%$.

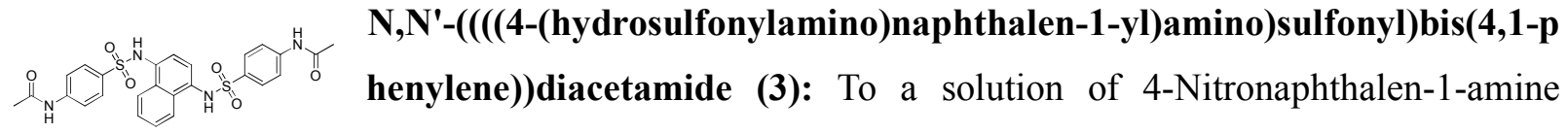
$(1.81 \mathrm{~g}, 10 \mathrm{mmol})$ in THF was added $\mathrm{Pd} / \mathrm{C}$. The reaction mixture was stirred under hydrogen for $4 \mathrm{~h}$. 
The solution was filtered to remove the catalyst. The filtrate was concentrated under reduced pressure to give the light yellow oil. The crude product, naphthalene-1,4-diamine, was used without further purification. 4-acetamidobenzenesulfonyl chloride $(5.14 \mathrm{~g}, 22 \mathrm{mmol})$ and pyridine $(2.37 \mathrm{~g}, 30$ mmol) was added to the solution of toluene $(20 \mathrm{~mL})$ and naphthalene-1,4-diamine. The reaction mixture was stirred at $100{ }^{\circ} \mathrm{C}$ for $2 \mathrm{~h}$ under nitrogen. After cooling to room temperature, reaction mixture was then diluted in $20 \mathrm{~mL}$ petroleum ether. After filtration, the solid was collected and washed with $1 \mathrm{M}$ hydrochloric acid. Recrystallization from acetonitrile gave the pink solid, yield 76\%; m.p.: 200-201 ${ }^{\circ} \mathrm{C} ;{ }^{1} \mathrm{H}-\mathrm{NMR}$ (300 MHz, DMSO, $\delta$ ) 10.34 (s, 2H), 10.05 (s, 2H), 7.99 - 7.97 (m, 2H), $7.69-7.66(\mathrm{~m}, 4 \mathrm{H}), 7.56-7.53(\mathrm{~m}, 4 \mathrm{H}), 7.41-7.38(\mathrm{~m}, 2 \mathrm{H}), 7.00(\mathrm{~s}, 2 \mathrm{H}), 2.07(\mathrm{~s}, 6 \mathrm{H})$; HRMS (ESI): found $570.1491\left(\mathrm{C}_{26} \mathrm{H}_{28} \mathrm{~N}_{5} \mathrm{O}_{6} \mathrm{~S}_{2},\left[\mathrm{M}+\mathrm{NH}_{4}\right]^{+}\right.$, requires 570.1476).



N,N'-((((cyanomethyl)(4-((cyanomethyl)(hydrosulfonyl)amino) naphthalen-1-yl)amino)sulfonyl)bis(4,1-phenylene))diacetamide (4): To a solution of compound 3 (1.104 g, $2 \mathrm{mmol})$ in DMF $(5 \mathrm{ml})$ was added $\mathrm{K}_{2} \mathrm{CO}_{3}$ (830 mg, $6 \mathrm{mmol})$ followed by bromoacetonitrile $(600 \mathrm{mg}, 5 \mathrm{mmol})$. After $3 \mathrm{~h}$ stirring at room temperature, the reaction mixture was then diluted in $30 \mathrm{~mL}$ water and quenched with $2 \mathrm{M}$ hydrochloric acid to $\mathrm{pH} 5$. The crude product was obtained through filtration. Recrystallization from ethyl acetate/n-hexane give compound 4 as a light gray soild, yield 53\%; m. p. :204-205 ${ }^{\circ}$; 1H-NMR (300 MHz, DMSO, \&) 10.45 (s, 2H), 8.08 (m, 2H), 7.81 (m, 10H), 7.14 (s, 1H), 7.05 (s, 1H), $4.96(\mathrm{~s}, 2 \mathrm{H}), 5.00(\mathrm{~s}, 2 \mathrm{H}), 2.12(\mathrm{~s}, 6 \mathrm{H})$; HRMS (ESI): found 631.1434 (C30H27N6O6S2, $[\mathrm{M}+\mathrm{H}]+$, requires 631.1428). HPLC $(70: 30$ methanol : water with $1 \%$ TFA $): \mathrm{t}_{\mathrm{R}}=8.9 \mathrm{~min}, 98.0 \%$.

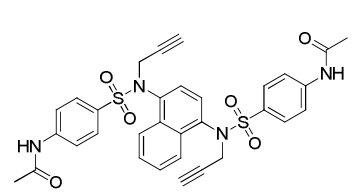

N,N'-(((4-(hydrosulfonyl(prop-2-yn-1-yl)amino)naphthalen-1-yl)(prop-2 -yn-1-yl)amino)sulfonyl)bis(4,1-phenylene))diacetamide (5): Compound 5 was synthesized according to the procedure of compound 4, light gray solid, yield 72\%; m.p.: 126-127 C; 1H-NMR (300 MHz, DMSO, $\delta) 10.40$ (s, 2H), 8.23 (m, 2H), 7.66 (m, 12H), $7.02(\mathrm{~s}, 1 \mathrm{H}), 6.90(\mathrm{~s}, 1 \mathrm{H}), 4.54(\mathrm{~s}, 4 \mathrm{H}), 2.16(\mathrm{~s}, 3 \mathrm{H}), 2.10(\mathrm{~s}, 3 \mathrm{H})$; HRMS (ESI): found 629.1526 $\left(\mathrm{C} 32 \mathrm{H} 29 \mathrm{~N} 4 \mathrm{O} 6 \mathrm{~S} 2,[\mathrm{M}+\mathrm{H}]+\right.$, requires 629.1523). HPLC (70 : 30 methanol : water with 1\%o TFA ): $\mathrm{t}_{\mathrm{R}}$ $=7.1 \mathrm{~min}, 96.7 \%$.

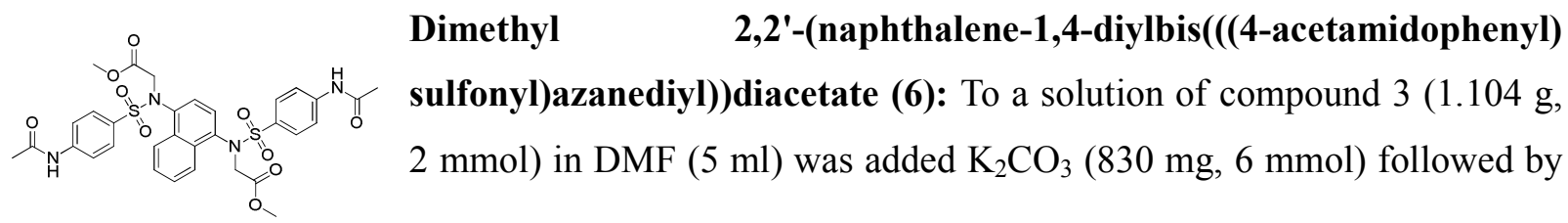


methyl bromoacetate $(765 \mathrm{mg}, 5 \mathrm{mmol})$. After $3 \mathrm{~h}$ stirring at room temperature, the reaction mixture was then diluted in $30 \mathrm{~mL}$ water and quenched with $2 \mathrm{M}$ hydrochloric acid to $\mathrm{pH}$. The crude product was obtained through filtration. Recrystallization from ethyl acetate/n-hexane give compound 6 as a light brown soild, yield 64\%; m. p. :131-132 ${ }^{\circ} \mathrm{C}$; $1 \mathrm{H}-\mathrm{NMR}(300 \mathrm{MHz}, \mathrm{DMSO}, \delta)$ $10.48(\mathrm{~s}, 2 \mathrm{H}), 8.30(\mathrm{dd}, 1 \mathrm{H}, J=6.3,3.1 \mathrm{~Hz}), 8.17$ (dd, $1 \mathrm{H}, J=6.6,3.2 \mathrm{~Hz}), 7.85$ (d, 2H, $J=8.6 \mathrm{~Hz})$, $7.73(\mathrm{~d}, 2 \mathrm{H}, J=8.7 \mathrm{~Hz}), 7.58(\mathrm{~m}, 6 \mathrm{H}), 7.09(\mathrm{~s}, 1 \mathrm{H}), 6.88(\mathrm{~s}, 1 \mathrm{H}), 4.52(\mathrm{~m}, 4 \mathrm{H}), 3.64(\mathrm{~s}, 6 \mathrm{H}), 2.05(\mathrm{~s}$, 6H); HRMS (ESI): found 697.1644 (C32H33N4O10S2, [M+H]+, requires 697.1633). HPLC (70 : 30 methanol : water with $1 \%$ TFA ): $t_{R}=5.8 \mathrm{~min}, 98.3 \%$.

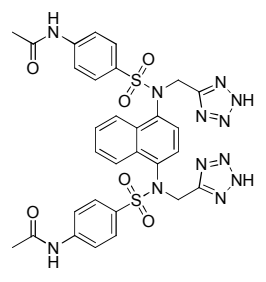

N,N'-((((2H-tetrazol-5-yl)methyl)(4-(((2H-tetrazol-5-yl)methyl) (hydrosulfonyl)amino)naphthalen-1-yl)amino)sulfonyl)bis(4,1-phenylene)) diacetamide (7): To a solution of compound 4 (630 $\mathrm{mg}, 1 \mathrm{mmol})$ in DMF (5 ml) was added $\mathrm{NH}_{4} \mathrm{Cl}(161 \mathrm{mg}, 3 \mathrm{mmol})$ followed by $\mathrm{NaN}_{3}(163 \mathrm{mg}, 2.5 \mathrm{mmol})$. The reaction mixture was stirred at $100{ }^{\circ} \mathrm{C}$ for $6 \mathrm{~h}$ under nitrogen. After cooling to room temperature, the reaction mixture was then diluted in $30 \mathrm{~mL}$ water and quenched with $2 \mathrm{M}$ hydrochloric acid to $\mathrm{pH} 5$. The crude product was obtained through filtration. Recrystallization from ethyl acetate/n-hexane give compound 7 as a light yellow soild, yield $67 \%$; m. p. :227-228 ${ }^{\circ}$; 1H-NMR (300 MHz, DMSO, $\delta) 10.46$ (s, 1H), 10.43 (s, 1H), 8.12 (m, 1H), 8.06 (m, 1H), 7.84 (m, 2H), $7.76(\mathrm{~m}, 2 \mathrm{H}), 7.56(\mathrm{~m}, 6 \mathrm{H}), 6.79(\mathrm{~s}, 1 \mathrm{H}), 6.75(\mathrm{~s}, 1 \mathrm{H}), 5.29-4.97(\mathrm{~m}, 4 \mathrm{H}), 2.16(\mathrm{~s}, 3 \mathrm{H}), 2.03(\mathrm{~s}$, $3 \mathrm{H}) ;{ }^{13} \mathrm{C}$ NMR (75 MHz, DMSO-d 6 ) $\delta$ 169.42, 169.21, 153.65, 153.35, 143.84, 143.80, 136.44, $136.00,133.02$, 132.93, 129.94, 129.18, 129.06, 126.92, 126.14, 123.96, 118.57, 118.49, 45.36, 44.92, 24.22, 24.14; HRMS (ESI): found 717.1771 (C30H29N12O6S2, [M+H]+, requires 717.1769). HPLC (70 : 30 methanol : water with 1\%o TFA ): $\mathrm{t}_{\mathrm{R}}=2.6 \mathrm{~min}, 98.0 \%$.

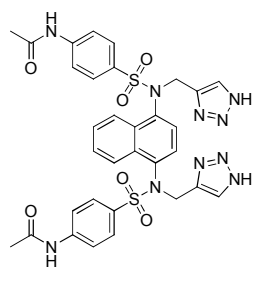

N,N'-(((((1H-1,2,3-triazol-4-yl)methyl)(4-(((1H-1,2,3-triazol-4-yl)methyl) (hydrosulfonyl)amino)naphthalen-1-yl)amino)sulfonyl)bis(4,1-phenylene)) diacetamide (8): To a solution of compound 5 (628 $\mathrm{mg}, 1 \mathrm{mmol})$ in DMF (5 ml) was added $\mathrm{NH}_{4} \mathrm{Cl}$ (161 mg, $\left.3 \mathrm{mmol}\right)$ followed by $\mathrm{NaN}_{3}(163 \mathrm{mg}, 2.5 \mathrm{mmol})$. The reaction mixture was stirred at $100{ }^{\circ} \mathrm{C}$ for $6 \mathrm{~h}$ under nitrogen. After cooling to room temperature, the reaction mixture was then diluted in $30 \mathrm{~mL}$ water and quenched with $2 \mathrm{M}$ hydrochloric acid to $\mathrm{pH} 5$. The crude product was obtained through filtration. Recrystallization from ethyl acetate/n-hexane give cmpound 8 as a light yellow soild, yield $63 \%$; m. p. :166-168 ${ }^{\circ} \mathrm{C}$; 1H-NMR (300 MHz, DMSO, $\delta) 10.43$ (m, 2H), 8.01 (m, 2H), 7.86 (m, 4H), 7.73 (m, 4H), 7.63 (m, 2H), 7.49 (m, 2H), 6.79 (m, 2H), 5.13 (dd, 2H, $J=14.2,2.9$ Hz), 4.77 (m, 2H), 2.15(s, 6H); HRMS 
(ESI): found 715.1866 (C32H31N10O6S2, $[\mathrm{M}+\mathrm{H}]+$, requires 715.1864). HPLC (70 : 30 methanol : water with $1 \%$ TFA ): $t_{R}=3.9 \mathrm{~min}, 98.1 \%$.

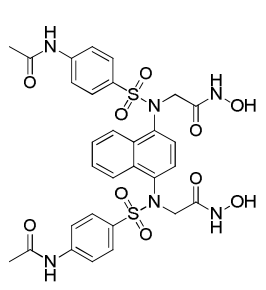

2,2'-(naphthalene-1,4-diylbis(((4-acetamidophenyl)sulfonyl)azanediyl))bis(N-h

ydroxyacetamide) (9): To a solution of compound 6 (696 mg, $1 \mathrm{mmol}$ ) in $\mathrm{MeOH}$ $(10 \mathrm{~mL})$ was added $\mathrm{NH}_{2} \mathrm{OH} \cdot \mathrm{HCl}(4.17 \mathrm{~g})$ followed by $\mathrm{NaOH}(1.2 \mathrm{~g})$. After $6 \mathrm{~h}$ stirring at room temperature, the reaction mixture was then diluted in $30 \mathrm{~mL}$ water and quenched with $2 \mathrm{M}$ hydrochloric acid to $\mathrm{pH}$ 5. The crude product was obtained through filtration. Recrystallization from ethyl acetate/n-hexane give compound 9 as a light yellow

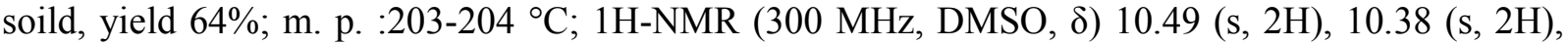
$8.92(\mathrm{~m}, 2 \mathrm{H}), 8.25(\mathrm{~s}, 2 \mathrm{H}), 7.81(\mathrm{~d}, 2 \mathrm{H}, J=8.1 \mathrm{~Hz}), 7.72(\mathrm{~d}, 2 \mathrm{H}, J=8.25 \mathrm{~Hz}), 7.57(\mathrm{~s}, 6 \mathrm{H}), 6.92(\mathrm{~m}$, 2H), $4.25(\mathrm{~m}, 4 \mathrm{H}), 2.11(\mathrm{~s}, 6 \mathrm{H})$; HRMS (ESI): found $699.1558(\mathrm{C} 30 \mathrm{H} 31 \mathrm{~N} 6 \mathrm{O} 10 \mathrm{~S} 2,[\mathrm{M}+\mathrm{H}]+$, requires 699.1538). HPLC (70 : 30 methanol : water with $1 \%$ TFA ): $t_{R}=4.1 \mathrm{~min}, 97.2 \%$.

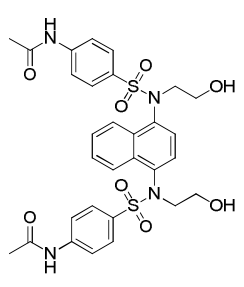

\section{N,N'-(((4-(hydrosulfonyl(2-hydroxyethyl)amino)naphthalen-1-yl)(2-hydroxyet} hyl)amino)sulfonyl)bis(4,1-phenylene))diacetamide (10): To a solution of $\mathrm{LiAlH}_{4}$ (75.9 mg, $2 \mathrm{mmol})$ in THF ( $5 \mathrm{~mL}$ ) was added a solution of compound 6 (696 mg, 1 mmol) in THF ( $5 \mathrm{~mL})$ dropwisely. After $1 \mathrm{~h}$ stirring in an icewater bath, $4 \mathrm{~mL}$ water was added to the reaction mixture. After stirring $20 \mathrm{~min}$ at room temperature, $4 \mathrm{~mL}$ of $15 \% \mathrm{NaOH}$ solution was added to the reaction mixture dropwisely, followed by another $20 \mathrm{~min}$ stirring. Then the reaction mixture was quenched with $12 \mathrm{~mL}$ water. The crude product was obtained through extraction. Recrystallization from ethyl acetate/n-hexane give compound 10 as a light gray soild, yield 61\%; m. p. :157-159 ${ }^{\circ} \mathrm{C}$; 1H-NMR (300 MHz, DMSO, $\left.\delta\right) 10.44$ (s, 1H), 10.40 (s, 1H), $8.26(\mathrm{~m}, 2 \mathrm{H}), 7.86(\mathrm{~m}, 4 \mathrm{H}), 7.68$ (d, 6H, J=4.86 Hz), 6.99 (s, 1H), 6.79 (s, 1H), 4.77 (m, 4H), 3.92 (m, 4H), 2.18(s, 6H); HRMS (ESI): found $641.1730(\mathrm{C} 30 \mathrm{H} 33 \mathrm{~N} 4 \mathrm{O} 8 \mathrm{~S} 2,[\mathrm{M}+\mathrm{H}]+$, requires 641.1734). HPLC (70 : 30 methanol : water with 1\%o TFA ): $t_{R}=3.9$ min, $96.0 \%$.

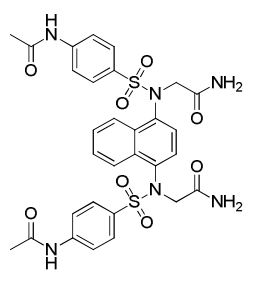

N,N'-(((2-amino-2-oxoethyl)(4-((2-amino-2-oxoethyl)(hydrosulfonyl)amino) naphthalen-1-yl)amino)sulfonyl)bis(4,1-phenylene))diacetamide (11): To a solution of compound 3 (1.104 g, $2 \mathrm{mmol})$ in DMF $(5 \mathrm{ml})$ was added $\mathrm{K}_{2} \mathrm{CO}_{3}(830$ $\mathrm{mg}, 6 \mathrm{mmol}$ ) followed by bromoacetamide $(690 \mathrm{mg}, 5 \mathrm{mmol})$. After $3 \mathrm{~h}$ stirring at room temperature, the reaction mixture was then diluted in $30 \mathrm{~mL}$ water and quenched with $2 \mathrm{M}$ hydrochloric acid to $\mathrm{pH}$ 5. The crude product was obtained through filtration. Recrystallization from ethyl acetate/n-hexane give compound 11 a light pink soild, yield 58\%; m. 
p. :186-188 ${ }^{\circ} \mathrm{C}$; $1 \mathrm{H}-\mathrm{NMR}(300 \mathrm{MHz}, \mathrm{DMSO}, \delta) 11.03$ (s, 1H), 10.62 (s, 1H), $8.41(\mathrm{~s}, 1 \mathrm{H}), 8.20$ (s, 1H), $8.0(\mathrm{~m}, 1 \mathrm{H}), 7.76(\mathrm{~m}, 1 \mathrm{H}), 7.53(\mathrm{~m}, 4 \mathrm{H}), 7.35(\mathrm{~s}, 4 \mathrm{H}), 7.18(\mathrm{~s}, 4 \mathrm{H}), 7.0(\mathrm{~m}, 1 \mathrm{H}), 6.65(\mathrm{~s}, 1 \mathrm{H})$, 4.25 (m, 4H), 2.15 (s, 6H); ${ }^{13} \mathrm{C}$ NMR (75 MHz, DMSO-d 6 ) $\delta 169.45,169.19,168.57,143.89,143.60$, $136.93,133.26,132.86,131.13,129.95,129.14,128.83,126.34,125.21,124.91,124.58,118.29$, 118.04, 54.15, 53.88, 24.13; HRMS (ESI): found $667.1644(\mathrm{C} 30 \mathrm{H} 31 \mathrm{~N} 6 \mathrm{O} 8 \mathrm{~S} 2,[\mathrm{M}+\mathrm{H}]+$, requires 667.1639). HPLC (70 : 30 methanol : water with $1 \%$ o TFA ) : $t_{R}=3.6 \mathrm{~min}, 96.6 \%$.

\section{Molecular Docking}

The Ligandfit docking tool in Discovery Studio, which has been validated for this target previously $^{2-3}$, was used to predict the binding mode of the designed small molecular inhibitor. The docking site was derived from the position of the small molecular ligand co-crystallized in the binding site of Keap1 (PDB code: 4IQK).

\section{Physicochemical properties Studies}

The $\mathrm{pKa}$ and partition coefficient ( $\log \mathrm{D}, \mathrm{pH}$ 7.4) were determined according to the methods of Avdeef and Tsinman ${ }^{4}$ on a Gemini Profiler instrument (pION) by the "goldstandard" Avdeef-Bucher potentiometric titration method ${ }^{5}$. The experiment was carried out as previously reported. ${ }^{6}$ The intrinsic solubility was determined by using the $\mathrm{pH}$-metric method, which is a new potentiometric acid-base titration method. The potentiometric solubility data were obtained with the pSOL Model 3 instrument (pION INC., Cambridge, MA, USA) and subsequently processed with the accompanying computer program, pS. Detailed procedures can be found in the references ${ }^{7}$.

\section{Biology}

\subsection{FP Competition Assay}

The FP assay was carried out as previously reported. ${ }^{2}$ The experiments were performed in the black nonbinding surface Corning 3676 384-well plates. The values were measured using a SpectraMax Multi-Mode Microplate Reader (Molecular Devices) with excitation and emission wavelengths of 485 and $525 \mathrm{~nm}$, respectively. All aqueous solutions were prepared using deionized water collected from a Millipore water purification system. The plates were loaded with $40 \mu \mathrm{L}$ of assay solution per well, consisted of $10 \mu \mathrm{L}$ of $4 \mathrm{nM}$ FITC-9mer Nrf2 peptide amide and $10 \mu \mathrm{L}$ of 12 nM Keap1 Kelch domain protein, $10 \mu \mathrm{L}$ of HEPES buffer, and $10 \mu \mathrm{L}$ of an inhibitor sample of varying concentrations. In this FP assay, the concentration of DMSO is less than $1 \%$. The plate was covered and rocked for $30 \mathrm{~min}$ at room temperature prior to FP measurements. FP was determined by measuring the parallel and perpendicular fluorescence intensity $\left(\mathrm{F} \|\right.$ and $\left.\mathrm{F}^{\perp}\right)$ with respect to the 
linearly polarized excitation light. We elected to use polarization in our quantitative analysis. The percentage inhibition of the competitor at each concentration point was determined by using equation \%inhibition = 1- (Pobs-Pmin) / (Pmax-Pmin). The values of Pmax, Pmin, and Pobs in the equations refer to the polarization of the wells containing Keap1 and the probe, the polarization of the free probe, and the observed polarization for the wells containing the inhibitors at a range of concentrations under the assay conditions. The $\mathrm{IC}_{50}$ of an inhibitor was determined from the plot of \%inhibition against inhibitor concentration analyzed by GraphPad Prism 6.0 software.

\subsection{Cell Culture Conditions and ARE-Luciferase Activity Assay.}

HepG2 cells stably transfected with a luciferase reporter (HepG2-ARE-C8) were kindly provided by Professor Dr. A. N. Tony Kong (Rutgers University, Piscataway, NJ) and Prof. Rong Hu (China Pharmaceutical University, Nanjing). Cells were maintained in modified RPMI-1640 medium (GiBco, Invitrogen Corp., USA) with 10\% fetal bovine serum (FBS) (GiBco, Invitrogen Corp., USA) and penicillin/streptomycin in a $37^{\circ} \mathrm{C}$ incubator with $5 \% \mathrm{CO}_{2}$. HCT116 cells (Cell Bank of Shanghai Institute of Biochemistry and Cell Biology, Shanghai Institutes for Biological Sciences, Chinese Academy of Sciences) were cultured in McCoy's 5A (Sigma-Aldrich, \#M4892, USA) supplemented with $10 \%(\mathrm{v} / \mathrm{v})$ FBS and penicillin/streptomycin.

The experimental procedures were carried out as reported previously. ${ }^{2}$ Generally, HepG2-ARE-C8 cells were plated in 96-well plates at a density of $4 \times 10^{\wedge} 4$ cells/well and incubated overnight. The cells were exposed with different concentrations of test compounds, with tBHQ serving as a positive control, DMSO as a negative control, and the luciferase cell culture lysis reagent as a blank. After 12 $\mathrm{h}$ of treatment, the medium was removed and $100 \mu \mathrm{L}$ of cold PBS was added into each well. Then the cells were harvested in the luciferase cell culture lysis reagent. After centrifugation, $20 \mu \mathrm{L}$ of the supernatant was used for determining the luciferase activity according to the protocol provided by the manufacturer (Promega, Madison, WI). The luciferase activity was measured by a Luminoskan Ascent (Thermo Scientific, USA). The data were obtained in triplicates and expressed as fold induction over control.

\subsection{RNA Extraction and qRT-PCR Analysis.}

We extracted total RNA of HCT116 cells using TRIzol reagent (Invitrogen). The experimental procedure of quantitative real-time RT-PCR was previously reported ${ }^{2}$. The RNA was reversely transcripted by using PrimeScript RT reagent kit following the manufacturer's instructions. The primers used for PCR can be found in supporting information. Quantitative real-time RT-PCR analysis of Nrf2 targeted genes NQO1, HO-1, and GCLM were performed by using the StepOne 
System Fast Real Time PCR system (Applied Biosystems). The values are expressed as the fold of the control. $\beta$-Actin was used for normalization.

Primers used for qRT-PCR are shown as follows:

HO-1

Sense primer: ATGGCCTCCCTGTACCACATC

Antisense primer: TGTTGCGCTCAATCTCCTCCT

NQO-1

Sense primer: CGCAGACCTTGTGATATTCCAG

Antisense primer: CGTTTCTTCCATCCTTCCAGG

GCLM-1

Sense primer: TTGGAGTTGCACAGCTGGATTC

Antisense primer: TGGTTTTACCTGTGCCCACTG

\subsection{Western blot analysis.}

Anti-NQO1 (sc-271116) antibodies and $\gamma$-GCS (sc-22755) antibodies were from Santa Cruz Biotechnology (Santa Cruz, CA, USA). Anti- $\beta$-action (AP0060) and anti-Nrf2 (BS1258) were purchased from Bioworlde (Bioworlde, USA). Anti-HO-1 (\#5853S) were bought from Cell Signaling Technology (USA). Isolation of cell fractions and Western blotting were performed as previously reported. ${ }^{2}$ Briefly, the extracts were separated by SDS-PAGE and then electrotransferred to PVDF membranes (Perkin Elmer, Northwalk, CT, USA). Membranes were blocked with 1\% BSA for $1 \mathrm{~h}$ followed by incubation with a primary antibody at $4{ }^{\circ} \mathrm{C}$ overnight. Then they were washed and treated with a DyLight 800 labeled secondary antibody at $37^{\circ} \mathrm{C}$ for $2 \mathrm{~h}$. The membranes were screened through the odyssey infrared imaging System (LI-COR, Lincoln, Nebraska, USA). 
$\mathrm{S} 2$. Densitometric analysis of the relative ratios of each proteins in western blot assay.
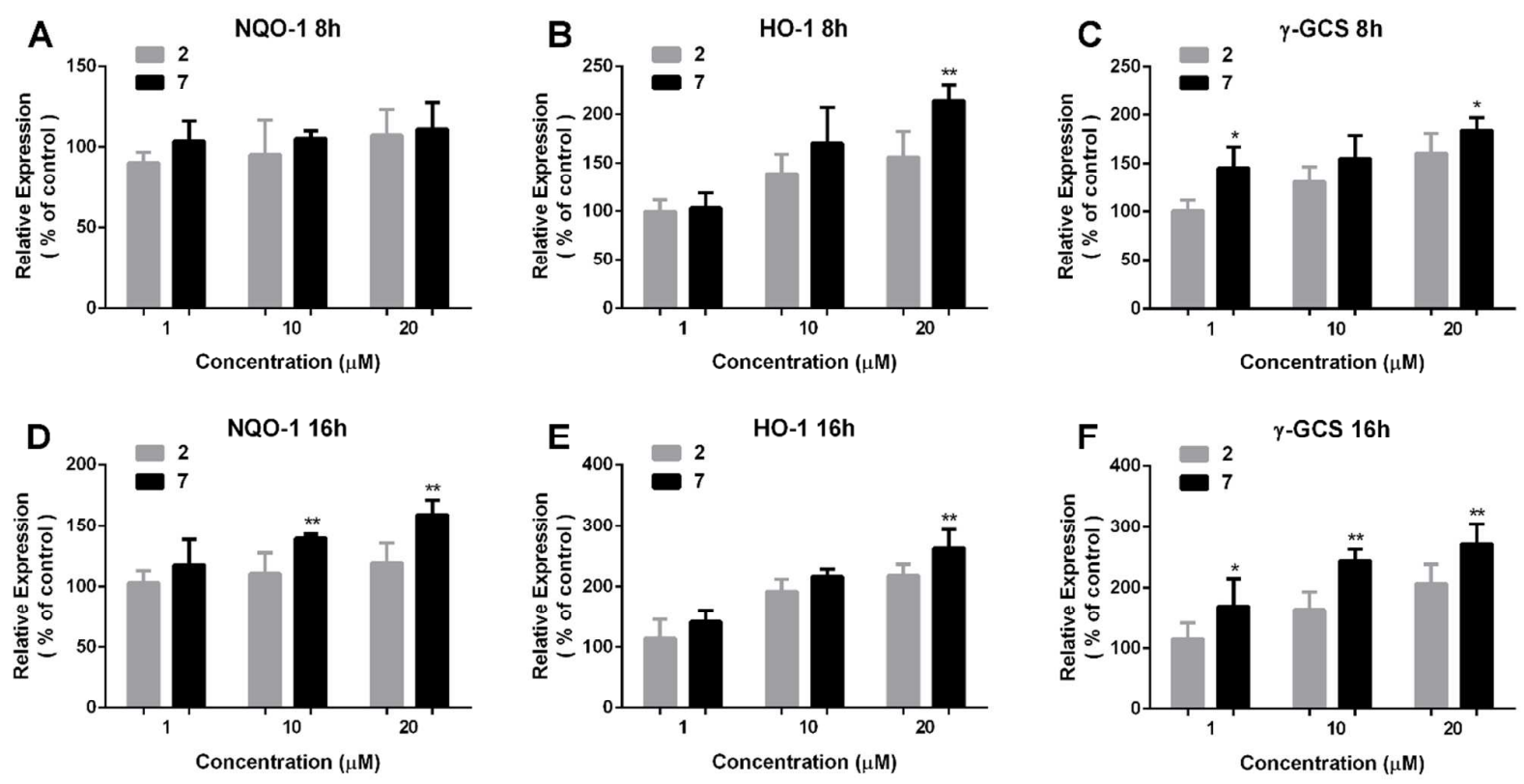

Figure S1. Densitometric analysis was performed to determine the relative ratios of each proteins. The data were normalized with $\beta$-actin expression and are expressed as the mean \pm SEM of three

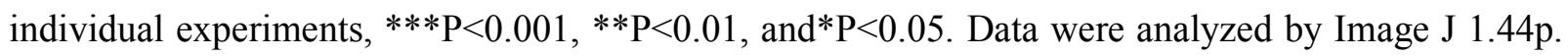
Expression of (A) NQO1, (B) HO-1 and (C) $\gamma$-GCS after 8 h treating with 2 and 7, respectively. Expression of (D) NQO1, (E) HO-1 and (F) $\gamma$-GCS after $16 \mathrm{~h}$ treating with 2 and 7, respectively. 


\section{References}

1. Jain, A. D.; Potteti, H.; Richardson, B. G.; Kingsley, L.; Luciano, J. P.; Ryuzoji, A. F.; Lee, H.; Krunic, A.; Mesecar, A. D.; Reddy, S. P.; Moore, T. W., Probing the structural requirements of non-electrophilic naphthalene-based Nrf2 activators. Eur. J. Med. Chem. 2015, 103, 252-268.

2. Jiang, Z.-Y.; Lu, M.-C.; Xu, L. L.; Yang, T.-T.; Xi, M.-Y.; Xu, X.-L.; Guo, X.-K.; Zhang, X.-J.; You, Q.-D.; Sun, H.-P., Discovery of Potent Keap1-Nrf2 Protein-Protein Interaction Inhibitor Based on Molecular Binding Determinants Analysis. J. Med. Chem. 2014, 57 (6), 2736-2745.

3. Sun, H.-P.; Jiang, Z.-Y.; Zhang, M.-Y.; Lu, M.-C.; Yang, T.-T.; Pan, Y.; Huang, H.-Z.; Zhang, X.-J.; You, Q.-d., Novel protein-protein interaction inhibitor of Nrf2-Keap1 discovered by structure-based virtual screening. MedChemComm 2014, 5 (1), 93-98.

4. Avdeef, A.; Tsinman, O., Miniaturized Rotating Disk Intrinsic Dissolution Rate Measurement: Effects of Buffer Capacity in Comparisons to Traditional Wood's Apparatus. Pharm. Res. 2008, 25 (11), 2613-2627.

5. Avdeef, A.; Bucher, J. J., Accurate measurements of the concentration of hydrogen ions with a glass electrode: calibrations using the Prideaux and other universal buffer solutions and a computer-controlled automatic titrator. Anal. Chem. 1978, 50 (14), 2137-2142.

6. Zhang, X.; Li, X.; Sun, H.; Wang, X.; Zhao, L.; Gao, Y.; Liu, X.; Zhang, S.; Wang, Y.; Yang, Y.; Zeng, S.; Guo, Q.; You, Q., Garcinia xanthones as orally active antitumor agents. J. Med. Chem. 2013, 56 (1), 276-92.

7. (a) Avdeef, A.; Berger, C. M., pH-metric solubility.: 3. Dissolution titration template method for solubility determination. Eur. J. Pharm. Sci. 2001, 14 (4), 281-291; (b) Avdeef, A., pH-metric Solubility. 1. Solubility-pH Profiles from Bjerrum Plots. Gibbs Buffer and pKa in the Solid State. Pharm. Pharmacol. Commun. 1998, 4 (3), 165-178; (c) Xi, M. Y.; Jia, J. M.; Sun, H. P.; Sun, Z. Y.; Jiang, J. W.; Wang, Y. J.; Zhang, M. Y.; Zhu, J. F.; Xu, L. L.; Jiang, Z. Y.; Xue, X.; Ye, M.; Yang, X.; Gao, Y.; Tao, L.; Guo, X. K.; Xu, X. L.; Guo, Q. L.; Zhang, X. J.; Hu, R.; You, Q. D., 3-Aroylmethylene-2,3,6,7-tetrahydro-1H-pyrazino[2,1-a]isoquinolin-4(11bH)-ones as Potent Nrf2/ARE Inducers in Human Cancer Cells and AOM-DSS Treated Mice. J. Med. Chem. 2013, 56 (20), 7925-7938. 